\title{
Three Low Key, But High Impact, Teaching Techniques for Undergraduate Biology Labs
}

\section{Lydia Chiasson}

\author{
Mount Royal University, Department of Biology, 4825 Mount Royal Gate SW, Calgary AB T3E \\ 6K6 CAN \\ (Imchiasson@mtroyal.ca)
}

\begin{abstract}
In this poster, I present three low key, but high impact, teaching techniques for undergraduate biology labs. I used paper cutouts, face paint and games to enhance student learning and engagement in Human Anatomy and Physiology labs. I used an interactive technique for blood typing, where students were given paper cutouts as a visual representation of $\mathrm{ABO}$ blood types that could be received and donated. My second technique used glow-in-the-dark face paint to help students understand the principles of epidemiology. By simulating a "glow-in-the-dark" virus, I demonstrated how viruses can be spread and lead to epidemics. For my third technique, students participated in a collaborative game to demonstrate flow of cerebrospinal fluid (CSF). Students moved throughout the lab as CSF, choroid plexuses (producing CSF) or arachnoid villi (absorb CSF). Although these techniques were applied in Human Anatomy and Physiology labs, their use can be expanded to a broad range of laboratories in science.
\end{abstract}

Keywords: blood typing, epidemiology, cerebrospinal fluid (CSF), interactive technique

Link to Original Poster File: https://doi.org/10.37590/able.v41.poster62

\section{Mission, Review Process \& Disclaimer}

The Association for Biology Laboratory Education (ABLE) was founded in 1979 to promote information exchange among university and college educators actively concerned with teaching biology in a laboratory setting. The focus of ABLE is to improve the undergraduate biology laboratory experience by promoting the development and dissemination of interesting, innovative, and reliable laboratory exercises. For more information about ABLE, please visit http://www.ableweb.org/.

Advances in Biology Laboratory Education is the peer-reviewed publication of the conference of the Association for Biology Laboratory Education. Published articles and extended abstracts are evaluated and selected by a committee prior to presentation at the conference, peer-reviewed by participants at the conference, and edited by members of the ABLE Editorial Board. Published abstracts are evaluated and selected by a committee prior to presentation at the conference.

\section{Citing This Article}

Chiasson L. 2020. Three low key, but high impact, teaching techniques for undergraduate biology labs. Article 62 In: McMahon K, editor. Advances in biology laboratory education. Volume 41. Publication of the 41st Conference of the Association for Biology Laboratory Education (ABLE). https://doi.org/10.37590/able.v41.abs62

Compilation (C) 2020 by the Association for Biology Laboratory Education, ISBN 1-890444-17-0. All rights reserved. No part of this publication may be reproduced, stored in a retrieval system, or transmitted, in any form or by any means, electronic, mechanical, photocopying, recording, or otherwise, without the prior written permission of the copyright owner.

ABLE strongly encourages individuals to use the exercises in this volume in their teaching program. If this exercise is used solely at one's own institution with no intent for profit, it is excluded from the preceding copyright restriction, unless 
otherwise noted on the copyright notice of the individual chapter in this volume. Proper credit to this publication must be included in your laboratory outline for each use; a sample citation is given above. 